\title{
A STUDY OF THE LABYRINTH OF CYPRINUS, IN PARTICULAR REFERENCE TO THE RELATIONSHIP BETWEEN HEARING AND SACCLUS
}

By

TADAHIKO MIYAZAKI, M.D.

Department of Otolaryngology, School of Medicine, Osaka University

(Director: Prof. Takatoshi Hasegawa)

Sound stimulation (256,512, 1024 and $2048 \mathrm{cps}$ ) was given to the fish (carassius auratus Linné) in water and hearing test was performed by observing the responses to sound, particularly the backing movement of pectoral fins.

The response disappeared when the lower portion of the labyrinth was destructed or the swim. bladder was ruptured, while the fish responded normally after the destruction of upper portion of the labyrinth, lateral-line organ and the sensory organs of the skin and the extraction of the lateral line nerve.

Morphological studies of the fish labyrinth were performed and the remarkable findings were as follows.

1) The whole labyrinth is found encapsulated in a semitransparent elastic membrane (Membrana propria), which histologically resembles bone tissue. There exists no space between the M. propria and the membranous labyrinth.
2) The sacculus is small but has a complica. ted structure. The infero-medial part of the wall (bridge), which is not covered by M. propria and histologically double-layered, makes up the laterosuperior wall of the cavity, which can be reasonably called as the perilymphatic space because of its direct communication to the intracranial space. The sagitta is fixed to the macula sacculi at the superior and inferior edge and its wing-like process touches the bridge.

3) Sound is transmitted from swimbladder to the sacculus via the Weberian ossicles, sinus impar and ductus communicans.

4) The macula sacculi is more densely innervated and vascularized than the macula of the utriculus and Lagena.

Morphologically, it seems reasonable to presume that the vibration of "bridge" be percepted by the sensory hairs of the macula sacculi.

\section{魚類コイ科の迷路特に球形囊と聴覚に関する研究}

大阪大学医学部耳鼾咽㟮科教室（主任：長谷川高敏教授）

$$
\text { 大学院生 宮 䐀 忠 这 }
$$

\begin{tabular}{|c|c|c|}
\hline \multicolumn{3}{|r|}{ 目 } \\
\hline I & 緒 & 쿨 \\
\hline II & 魚類 & 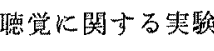 \\
\hline & 。䒠 & 動物 \\
\hline 2 & . 实 & 方法 \\
\hline & . 手 & 処䈯 \\
\hline 4 & . 成 & 频 \\
\hline & . 考 & 察 \\
\hline
\end{tabular}

II. 魚類の迷路の形態に関する研究
1. 材 料

2. 然体㩆微竸に上る観察

3. 組織学的歈索
a) 研発方法
b) 成績

4. 考察

$$
\text { N. 結涪 }
$$

附図 


\section{I. 緒害}

古くギリシヤ時代より Aristoteles, Plinins 等は魚に 耳石があり，聴覚に関係すると考克ていたが 17 世紀以 後, Casserius, Klein. Geoffroy, Comparetti, Scarpa, Weber, Lang, Hasse 等により魚の内耳の形態学的研 究がなされ，程釱的事実とともに，魚に聴覚のあること が広く僄じられていた，1857 年 Helmholtz が㯖覚に 関して共鳴説を述べ，一方では Retzius, Nussbaum, Wright, Keibel, Krause, Bierbaum 等により魚類内 耳の形態学的, 組織学的, 発生学的知見が豊富となつた か゚，魚には共鳴すべき基礎膜は見出されず，耐楱類で始 わて Papilla basillaris を有することが分り，魚の聴覚 を否定する説が現われた123).

しかし今世紀に入つてからは，精密な生理尖跧が行わ 丸, Parker (1902), Parker, van Heusen (1917) 4), Manning (1924)の等は魚の音に対する反応を証明し た，条件づけの矿究方法を導入することにより害験はさ らに精度を增し, von Frisch(1936) 6), Dijkgraf(1936) 6), 長谷川 (1952) 12), 大久保 $(1947)^{8)}$ 等の研究によ? て魚の聪覚は確実視されるるに至つた ${ }^{16)}$.

しかるに魚類の聴覚感受部位はどの器官にあるかなか 学説が一致过ず, Manning ${ }^{6)}$ は Lagena, 卵形嫼, 侧

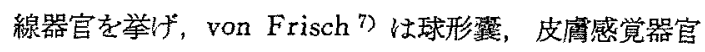
を, parker, van Heusen ${ }^{4)}$ は Lagena, 側線器官を, de Burlet ${ }^{11}$, 長谷川 ${ }^{12}$, 大久保 ${ }^{8)}$ は球形翼を, Katsuki 9) 10) は側線器官を主張している.

Werner ${ }^{13)}$, von Frisch 7), de Burlet ${ }^{11)}$, 長谷川12)

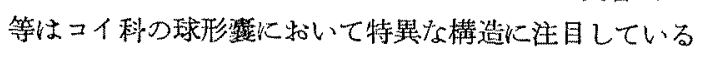
が，魚類内耳の形態学的研究は少なく，詳細はなお明 らかではない，著者は淡水魚で最も聴覚が良いとされ ているコイ科型内耳を持つものの中から、コイ科フナ Carassius auratus Linné を選んで聴覚に関する垁験 を行い,さらにその迷路の詳細な組織学的研究を行つて 形態を明らかルし，聴筧嘰能を考察した。

\section{II． 魚類の㯖営に関する実験}

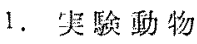

体長 $15 \sim 18 \mathrm{~cm}$ のコイ科フナ Carassius auratus Linné を用いた，来験に際して，体勢，運動，表皮に 異常のないことを確認した。

\section{2. 実鈳方法}

魚に音刺滶を与え，实行器に現われる反応を観察し な ${ }^{15)}$ 。刺激としては Bezold-Edelmann の連続音文， $c^{1}(256 \mathrm{cps}), c^{2}$ (512cps), $c^{2}$ (1024cps), $\mathrm{c}^{4}$ (2048cps), t
用い，水槽壁に強制振動を起さ世，水中の魚に音刺激を 与えた，音又柄とガラス壁の衝笑音をさけるため，薄い

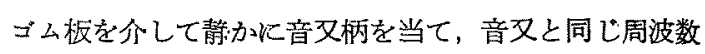
の音を水中に伝えた ${ }^{8}$ ，視覚への刺游を除くため，水槽 全体をボール紙で括括い，採壮，刺激，観察のため三つ の小管を開けて，無留室内で実歌を行つた。

音に対卞る魚の反応として先人は種々のものる挙げて (る395) 8). 著者は強度，周波数の異なる数種の音刺激， 振動，光刺激，水旅などを魚に与えて詳細に観察した結 果，音剩激に特舅的であり，かつ最も哥邪激で現われ る反応は，胸鰭を前方に扰げる反射であることを知り， この実歌の聴覚反射として用いた。

この反射は音を与えた直後に，両側の胸解を同時に前 今へ動かし，筧条間を扰げる反応で，映画に撮影して計 測すると、刺激の始まりから約 0.5 秒持続して後に止む

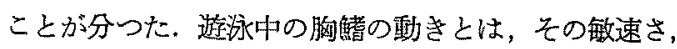
動きが大きいこと，音刺激に同調することから区別し得 る. 奏験は酸素量の十分な水中で魚が静㩊になつてから 行 ることを微察した（写蒖1).

3. 手術処犆

手術に先立つてすべての魚に聴覚反射を検して正常で あることを確かめ, 各種感覚器を除く手術を行つた.

a) 迷路上部の破壊

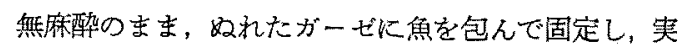
体影徏鏡の下で額毟上部又は頭項骨の側方にコの字型に

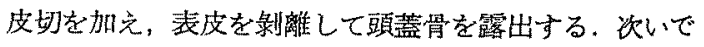

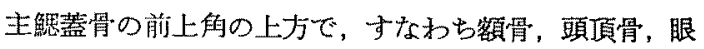
下骨，鯀骨の接合部で $4 \times 6 \mathrm{~mm}$ 程度の長力北の空を開 けて頭蓋内に入る。黑色色素の多い硬脳膜を切開し，魚

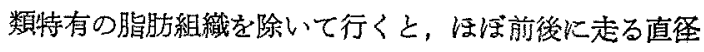
䄪 $0.5 \mathrm{~mm}$ の前半規管を見る。これをたとつて後半視

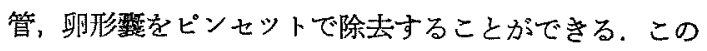
踏，視葉，小脑，延噵，迷走神経葉の損賃を極力さけな ければならない，手術は3〜5分で終り，魚はこの間の 酸素久乏に十分耐えられる.つついて坟側の手術を行う ことす可能である. 術後，綿を術創につめて実験に供す る.手術の失敗は出血過多，中枢神経損㑺などで，これ らは列験加除いた。

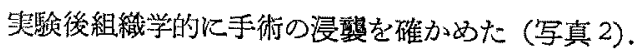

b) 迷路下部の破壊

脳幹の直下にある骨腔内の 迷路である球形囊および Lagena を破㯖することは，かなり困難で著者は次の上 
らな方法を用いた，無麻醉のまを鰓蓋の後上部をくさび 形飞切除し，第一鰓亏を注意樑く剥離して，その上部内 面を通る第四神経の枝を傷つけない上うに浮かせて，

Lagena 外側部を剥離する. Lagena 外側壁を前後に走 る軟骨部より 小ピンセットで Lagena とその内側の球

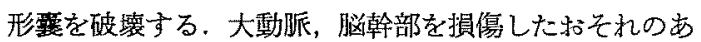
るものは実駼から除いた，手術は両側を続けて行つても 約 5 分で終り，術創に綿をつぬて実験に供する。

実験後組織学的検萦により手術の浸琵を確かめた（写 真 3 ).

c）側線神絽の拔去

鳃蓋裂の直後で，鳞を除き皮切を加えて側線神経を露 出する、ピンセットで静が引き抜けば尾部迄抜去する ことができる，無麻酔で両側同時に行つた。

\section{d）硝酸銀全身塗布}

側線器官は体側のみならず頭部にる豊富に分布するた め，前記の手術ではな招不完全である，そこで全身の側 線器官と，皮膚感覚器官を除去するため，硝酸銀による 烍灼を行つた．まず体表の粘液を乾燥したガーゼでよく 拭さとり，2\%硝酸鍉液を全体表に整布した，表皮は白 色となり角膜も白罚与る，組織学的に皮盛感覚器官，側 線器官の高度の破壊を証明した（写真4).

e) 镖穿刺，脱気

䱾は平衝器, 聴器と関逞を有するといら説が多く、こ の機能を除くため䧗部正中線より心臟をさけて注射針で 穿刺を行い，解の前房内のガスを拔いて实験した．

\section{4. 成綪}

実験は水槽に 2〜3匹のフナを入れて，しばらく水温 に慣らし，筑泡によって酸素を十分に溶かした上，魚の 静穏になるのをまつて無響室で行つた。

\section{未処置群}

84 匹のらち76 匹は四種の音刺激汇聴党反射を示し た． 5 匹は $\mathrm{c}^{3}$ または $\mathrm{c}^{4}$ の音又に反応せず，残りの 3 匹沈応が出なかつた。

迷路上部破壊群

一側破買の17 匹のらち9 匹は術後に手術側を下に乙 て横転し，健側を品にした弓状の体勢をとり，遊泳は不 活潠となり，健側の胸鰙，腹解の緊張が搦くなつた（写 真 5,6$)$. 残る 8 匹正常の体勢で解に 異常を認めなか つたが，遊泳は衍前より不活潑となり，強制的にとらし めた異常体勢からの復元が遅くなつた．聴覚反射を観察 すると，四種の周波数の刺激にすべて反応を示した．

両側の破罣に成功した 13 匹のうち 8 匹は横転して弓
状の体勢をとり，他の 5 匹む遊泳が不活濑で，回泳，揄 転運動が多く，正常の遊泳は不能となつた，聴覚反射は 10 匹で四種の周波数沈反応し，3匹は $\mathrm{c}^{1}, \mathrm{c}^{2}, \mathrm{c}^{3}$ の三種 に反応した，全般にこの群では胸觯の緊張が悪く反応は やや鈍であつた。

\section{迷路下部破壇群}

一側破壊を 10 匹に行つた，術後の体勢恃正常で，遊 泳状態は少し不活㴊になる程喥で 翼常運動はなからた (写真 7). 聴覚反射を検すると四種の刺激のすべてに反 応をみた。

両側破濖は 9 例成功し，術後の体勢，運動を観察した が，一側破壊例と同様に汪と儿ど正常であつた。しかし 聴喾反射をみると四種の周波数のいずれにも反応はみら れなからた。

\section{側線神経拔去群}

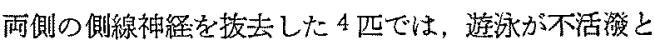
なり，静止していることが多かつたが，休勢に変化はな かつた．聴覚箺験では四種の音刺激に明瞭な区応を示し た.

\section{硝酸銀梁布样}

7 匹に硝酸銀滁布を行つたが，体勢に異常はなく，自 発的運動は汪とんど行放ず，静止していた，聴覚反射は 正常で四種の周波数の刺激によく反応した.

嗮穿刺群

3 匹を実験した，術後魚は水底に沈んで自発運動はは とんど行わなくなつた (写真 8$)$. 全例に聴覚反射は消失 していた.

以上の成績の概略を第 1 表に示す

第 1 表 手術後の聴喾実験の成紩

\begin{tabular}{|c|c|c|c|c|c|}
\hline 手 術 & 聴覚反射 & 体 & 梦 & 運 & 動 \\
\hline 迷路上部破塧 （一側） & あり & 異 & 常 & 異 & 常 \\
\hline （峏㑡） & あ & 異 & 常 & 異 & 常 \\
\hline 迷路下部破墔 （一倒） & あ & 正 & 常 & ほ嘼正 & 常 \\
\hline 同上 上 (两侧) & $な$ & 正 & 常 & 注注正 & E常 \\
\hline 側線神経拔去 （両側） & あ & 正 & 常 & 減 & 弱 \\
\hline 硝酸銀全身塗布 & あ & 正 & 常 & 減 & 弱 \\
\hline 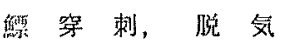 & な & 異 & 常 & 翼 & 常 \\
\hline
\end{tabular}

\section{5. 考察}

魚の聴覚䒠駼，特に感受部位の推察のためには，水中 での実験が必要であると思われる，空気中の実験では， 音響インピーダンスが空気と水で非常に異なること（空 
気の音響インピダンス $Z_{\mathrm{A}}=42 \mathrm{cgs}$, 水妒 $\mathrm{Z}_{\mathrm{F}}=145000$

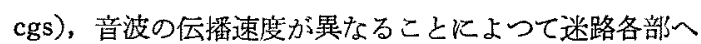
伝わる音響エネルギーが变つてしまらからである，そこ で著者は定量的実験が不可能であつたが（魚の方位，距 離の变動, 水槽壁の複雑な反射のため), 水中実覧によ り自然な状態での聴覚実験を゙行つた。

音に対する魚の反応としてこれまで挙げられてきた多 くのものは出現が不確実, 不明膫で成績がそろわないた め，前述の聴覚反射のみを用いて良い結果を得ることが できだ

手術は後述の形態学的研究と平行して行つたので術技 は比較的容易で, 些験後の組織学的検索によつても手術 浸翼の限局していることを確かめることができた。

実験成續より見れば，聴覚に必要な 部位は迷路下部 とこれ関連する Weber 器官 (鱏, Weber 氏小骨, Sinus impar) であることが推察される.

\section{III. 魚類の迷路の形態に関する研究}

1. 材 料

体長 $15 \sim 18 \mathrm{~cm}$ のフナおよび $5 \sim 15 \mathrm{~cm}$ の金魯で，体 勢, 運動，体表以異常索認めず埴覚反射が正常のものを 用いた。

\section{2. 実体顕微鏡比よる観察}

フナを生体のまま，あるい性固定後，または固定脱灰 後解剖を行い，双眼実体顥微鏡下に観察した，迷路打よ び Weber 器官の概要を略述すれば，次のごとくであ る.

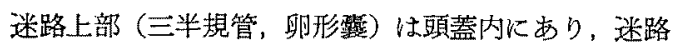
下部（球形殧，Lagena）ととむに半透明で弾性のある 膜に包まれている(写真9)。卵形硶の位置山眼球の後 方，主鮊蓋骨前上角の下方で中脳 (視葉)，小脑の外側 にあり，三半規管は哺乳動物と較べて大きく，体長約 $18 \mathrm{~cm}$ のフナで半規管の直径が約 $7 \mathrm{~mm}$ もあり, 前半規 管，後半規管の上部は頭頂骨の直下に至つている。迷路 上部は骨腔内ではなく，硬脸膜と軟脳膜の間にみられる 魚類独特の脂肪組織の中に理もれているが，外側半規管 の外側の一部は骨性の管の中を通つている．前半規管と 外側半規管の膨大部は前方にあり，後半規管のそれは後 万沉つて, 前半挸管の後脚部之後半規管の前脚部之は 合して総脚となることは哺乳動物と変りがない：この総 脚の部分では黒色色素の沈着が多くみられる。

卵形露の後部は細くなつて連酸管となり，後下方へ向 つて頭蓋腔を出て骨腔に入る，この骨腔は迷走神経葉，

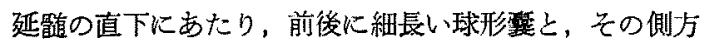

で鰓弓起始部に膨出した Lagena が入つている. Lagena は球形襄上りかなり大きく，前後径がやや長い瓜状 体で, 左右の Lagena の長軸は前方に約 60 度の角度で 開いている. 第八神経は卵形垔下部から膨大部一行くも のと，分れて連襄管とともに骨腔に入り球形覆， Lagena 几行くものを認める. 卵形襄，球形霆，Lagena $儿$ は各一個の非常に硬い耳石がある（写真 10)。卵形垔の 耳石 Lapillus は小さな円艋状で上面は凹，下面が凸と なり，辺縁は滑らかである，各耳石を採取後，一昼夜純 アルコール，想水エーテルの等量液に漫して，表面の脂 肪や組織液を除いたのち Sartrius 直示天科を用いて計 量した結果, Lapillus 注約 $1.3 \mathrm{mg}$ (10 個平均 $1.28 \mathrm{mg}$ ) であつた. 球形践の耳石 Sagitta は小さな桿状で，長 さ約 $5 \mathrm{~mm}$, 重量約 $0.5 \mathrm{mg}$ (平均 $0.48 \mathrm{mg}$ ) であり， そ の長軸恃球形覆の長軸とほぼ一致している。形態は特に 複雑で他の二種の耳石とは全く異つている. 模式図 (写 真11）に示すごとく，前方頭部に薄いいら状突起 (K)， 下部队は広い翼状の部分（F）があり，その下縁はこま かいのこぎり状をなしている，体部は中央で一度高まり (横䋎が最も厚い)，後方へ行くにしたがつて細くなつて 尾部を形成している.内面 (IF) は凹の粗面で，前後炕 走る鋭い稜が上下二本 $(\mathrm{cv}, \mathrm{cd})$ あり，尾部の前部まで つづいている. 外面 (AF) は凸の粗面で, 翼部 (F)は 特に薄い板状で半透明であり，前後方向と，前上方から 後下方に走るこまかい細条が多くみられる。 Lagena の 耳石 Asteriscus 㵊も大きく(重量平均 $15.60 \mathrm{mg}$ ), ほぼ円盤状で内面中央にくぼみがあり，それを囲んで環 状の溝がみられる. 外面はゆるい凸の粗面であり, 辺縁 は粗いのこぎり状となつている。

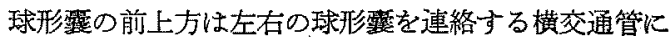
交通していて，この管は後方へ Sinus impar となつて 骨腔中を後へ走り，第一椎骨の位置に至つて左右に分れ て, Atrium sinus imparis として終る. Atrium の出 口は Weber 氏小骨の Scapium がふさぐ形で接してお り,さらに結合織で Intercalarium, Tripus と連つて, 僄前房の外層と緊密に結合している.

以上を模式図に表施ば，写真 12 のごとくである。

3. 組織学的梌索

a) 研究方法

固定法：断頭して雨眼より吻側部，下顎部，鰓蓋等 不要の部分を切除し，直ちに材料を固定夜に浸した. 固 定中は頭部を正常位置に保つように注意した，固定時間 は固定液，染色法に上り異なるが，多くは8〜21 日間 
で，檤鞘染色を行らるのは8週間を要した．固定の始め 約 24 時間は液を $4^{\circ} \mathrm{C}$ 程度に保つて冷固定を行つた。固 定液も種々検討したが，使用した液は，ホルマリン10 $\% ， 20 \%$ 液 (銀染色には中性ホルマリン液)，ホルマリ ン、エタノール液，Wittmaack 氏液，Zenker 氏液， Orth 氏液, Müller 氏液である.

脱灰法：脱灰には次の四種を用いて检討した．5\%硝 酸 9 , ホルマリン1（約一週間浸し $5 \%$ 硫酸ソーダ夜で 中和)，婊塩酸 8 ，濃嶬酸 12 ，水 80 (10 日間漫し $70 \%$ フルコールで洗涤), Plank-Rychlo の脱灭液 (2 日間), $10 \%$ EDTA 液 (8 日間).

包埋法：脱扊後アルュールで脱水して，ッエロイジ ン包埋, パラフイン包埋, ッエロイジン・パフイン包 埋を儱用した。

染色法：目的により次の六種の染色を行つた。へマ トキシリン, エオシン重染色，アザン染色，クルチッキ 一咀鞘染色，ワンギーソン染色，鈴木式銀染色.

b) 成 績

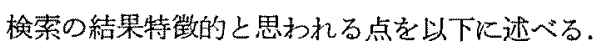

固有膜 Membrana propria

魚の迷路は高等動物と異なり，特有の膜に包まれてい

る.この膜は絽織学的に無構造の基質の中に細長い小腔 が散在して，その中に細胞を有している．この基質は骨 や軟骨とは黑なる染色性をむち第 2 表のごとき結果を得 た.

第 2 表 フナの頚部骨，软骨，固有膜基留の染色性

\begin{tabular}{|c|c|c|c|}
\hline 染色法 & 骨基 質 & 樕骨基留 & 固有膜基䓄 \\
\hline H.E 染色 & $\mid$\begin{tabular}{c|} 
Eosin \\
に丧染
\end{tabular} & $\begin{array}{c}\text { Hemato- } \\
x y \operatorname{lin}\end{array}$ & $\left.\right|_{\text {に淡染 }} ^{\text {Eosin }}$ \\
\hline Azan 染色 & $\begin{array}{c}\text { Azoca- } \\
\text { rmin }\end{array}$ & Anilinblau & $\begin{array}{r}\text { Anilinblau } \\
\text { 淡染 }\end{array}$ \\
\hline van Gieson 染色 & Fuchsin & 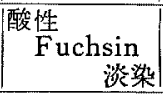 & 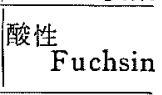 \\
\hline $\begin{array}{l}\text { Resorcin-Fuchsin } \\
\text { Azocarmin } \\
\text { Naphthol-grün } \\
\text { Orange G配合染色 }\end{array}$ & $\left|\begin{array}{c}\text { Nptho- } \\
\text { lgrün }\end{array}\right|$ & $\begin{array}{l}\text { Resorcin- } \\
\text { Fuchsir }\end{array}$ & $\begin{array}{l}\text { Naphtho- } \\
\text { lgrün に淡 } \\
\text { 染 }\end{array}$ \\
\hline
\end{tabular}

第 2 表のごとく，固有膜の基揗は弱い好酸性を示し， 染色性よりみて骨の基質より眯構, 煄骨の基質より密構 であることを知つた，小腔中の細胞はへマトキシリンに 濃染する細長い核を持ち，鈴木式銀染色によつて細胞質 の細い突起が互に連絡していることが分つた (写真 13). このよらな榡造は骨組織に最も近いものと思われる。
固有膜の内面は内被膜に雯打ちされていて，雨者の間 に腔は認められない，神経，血管がこの固有膜を買い て, 内被膜に至つている.

\section{三半規管 Ductus semicirculares}

魚の三半規管は頭蓋内の大きな部分を占めており，厚 、固有膜（内被膜の 5 10倍の厚さ）に包まれて，内被 膜があり，内リンパ腔を囲んでいる. 半規管の断面の直 徍は 0.5 0.6mm, 固有膜の厚さは $50 \sim 100 \mu$ で, 総脚

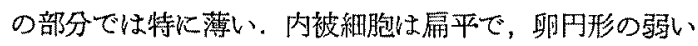

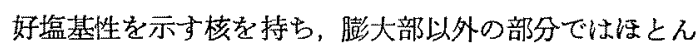
ど血管や神経をみない（写真 13)，三つの膨大部で内被 細胞憾覚細胞と支持細胞に分化して，膨大部稜を形成 し，その上には Cupula を見る。

甽形襄 Utriculus

卵形露の前半部に扣いて内被細胞は底部，前壁，側壁 にわたつて Macula utriculi を形成する、䣕形摆を包 さ固有膜は三半規管のそれより薄く，内側な小脳，中脳 と签脳膜を介して相佼して扣り，下面，側面から神経， 伹管が入つている (写真 14)。クルチッキー染色でみれ ば，有䯣神絽も多くあり，また一切片で数本の三大な神 经線維 (giant nerve fiber) が固有膜を貫いて Macula に入るのを見る. Macula utriculi は1〜2 層の支持細 胞と有毛の感覚細胞よりなるが，この感覚細胞は球形蔡 や Lagena のものに較べて背が低く，核は円形に近い (写真 15). 耳石は底面と外側面で Randfasern によつ て固定され，Macula の上飞位置するが，脱欧等の操作 のため緶小著しく，外側部からはずれることが多い（写 真 14). 耳石の Macula に面する部分は Matrix が粗

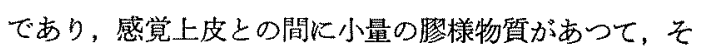
の中に感覚毛が入つている. 卵形畋の後部は固有膜と内 被膜のみとなり，細くなつて骨腔に入り，連露管を通つ て我形覆の前部之交通している(写真 16).

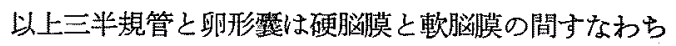
Cavum subdurale の脂肪組織の中にある.

球形蔆 Sacculus

連籊管 Ductus utriculosaccularis は骨腔に入つて細

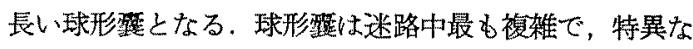

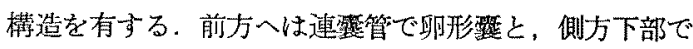
小孔により Lagena と，前部上力で横交通管により反

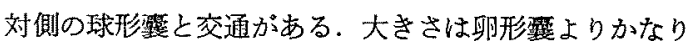
小さく，体長約 $15 \mathrm{~cm}$ のフナで前後 $6 \sim 8 \mathrm{~mm}$, 上下約 $2 \mathrm{~mm}$ である. 前半部 Lagena との交通部より前方で は，側壁に前後に走る稜があり固有膜が厚くなつてい 
る.これを外侧稜と呼ぶことにする（写真 17,18$)$.内 側下方では固有膜の存在しないところがあり，内被膜は 外リンパ腔の内皮に接して，膜状をなし，内リンパ膑と 外リンパ腔を境しているが，これを体長軸に直角の断面 でみると橋状に見えるので橋部と乎ぶことにする（写真 17).この橋部の下の外リンバ腔は前方で骨腔を出て, 頭蓋内の Cavum subdurale に交通していることを知 つた (写真 18).内被膜は内側壁で Macula sacculi を 形成する. Macula では 1〜2 層の支持細胞の核の上に 背の高い感覚細胞が並び，その感覚毛は Macula の上 の膠様物質の中に入つている (写真 19，23）. Macula の下の固有膜には非常に多くの血管と神経が通り，神経 は主として Macula の上縁，下縁において 基底膜を貫 いて，感覚細胞底部で網状となつている（写真 20，21）. クルチッキーの䯣鞘染色によれば，有㵦神経も多く，有 铕のままで基底膜を貫いて入る線維を認めた（写真 22). 血管の多いことも特幑で，Macula の中央部では基底膜 の下に接して小血管が集中している（写真 22，23）。 む ろ九畉形整や Lagena の Macula よりはるかに血管と 神綎が多い、内被膜の細胞は外側棱の部分で特殊な分化 を示している，すなわち細胞の背が高くなり，細胞質の 好酸性強く，核は小さい球形で強い好鲑基性を示してい る(写真 24)，またこの細胞群の下には小血管が来てい て一般の血管条 (Striavascularis) に相当するものと思 われる.

前述のごとく球形献の耳石 Sagitta は極めて小さく， 特別の形態を有する (写真 10,11，23). Macula との閔

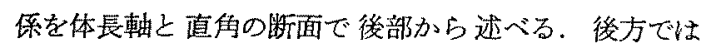
Macula の上下烽は小さく，その上の膠栏物質が多くな つていて, Sagitta の尾部はその上に浮いたよらな形 で, Randfasern によつて Macula の上下縁に固定さ れている. Randfasern の付着部で感覚槒胞はなく， 支持細胞のみ見られる（写真 19，20）。中央部では外下 万に Lagena との交通があり, Sinus impar は上方に 見られる(写真 22,25$)$.さらに前方では横交通管によ

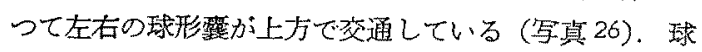
形贾の内下方固有膜に包まれないで内リンパ腔と外リ ンパ腔を境して膜状（橋部）に見られる（写真 17，26）。 Macula の上下径快大くなり，神経が基底膜下部に多 くなる. Macula の上には Sagitta の内面との間に膠 様物買があり，感覚毛が入つている. Macula の上緑炕 は Sagitta の上稜が，下縁には下稜が固着していて， 注目すべきことは Sagitta の翼部の先端が橋部の内被
膜に接着していることである（写真 17，23，27），強拡 大で見れば，この接着部の上を均質の薄い膜が括抏つて いる(写真 23，27，29）. Sagitta の上下棱の固着部であ る Macula の上下縁の細胞は，非常に背の高い細胞で， 細胞質は明るく，核は底部にあり，支持細脆に似てい る(写真 20). この細胞は上下緑共 5〜6.列見られる. Sagitta の翼部，上下稜，Macula，橋部の関係は考察で 述べるよらに，機能上大きな意義を持つものと考充られ る。橋部は二欋の細胞よりなり，一つは好酸性の大きな 細胞質とへマトキシリンに濃染する小球形の核を持つ上 皮細胞で，他の一つは扇平で明るい細胞質とへマトキシ リンに淡染する卵形の大きな核を持つ内皮細胞である (写真 28).この内被膜の橋の下の腔は，前方で頭蓋内 へ交通しているので，外リンハ腔と考えてよいと思われ る(写真 18 ).

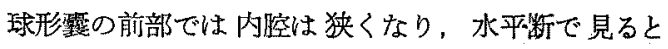
Sagitta の頙部が橋に接着して，連露管の力へのびてい

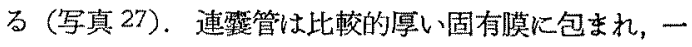
部㺅等部がある(写真 16).

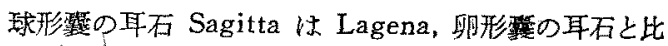
較して， 々の Matrix の密度が高いことを配合染色に より認めた。すなわち Lagena, 卵形嚄の耳石は Matrix が粗構であり，Azan 染色では Anilinblau に染るが， Sagitta は大部分が Azocarmin 飞染り，体部の一部の み青色にみられるのである。従つて脱灰雤作による耳石

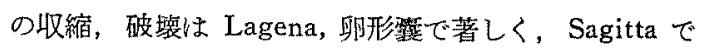
は少いので細かい棈造がよく保たれている。

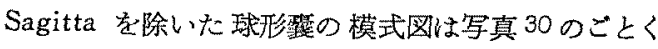

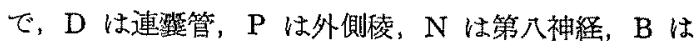
橋部，L は Lagena との交通孔， C は横交通管，M は Macula sacculi, S は Sinus imper を示してい 名.

Lagena

コイ科型の内耳では Lagena が球形整より大きい1). 体拫軸に直角の断面では下方に头つた卯円形，水平断面

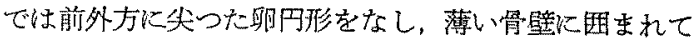

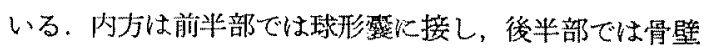
をへたてて，反対側の Lagena と対している. Sinus impar は Lagena の内上方を通つている (写真 31). Macula は内側壁のほぼ中央部, 球形缼との交通部を中 心比跤的大きく，耳石の内面と対している，耳石との 間には少量の膠様物質があり，感覚毛がその中に入つて いる，感覚細胞は Macula の中心部で背か゚高く，卵形 
の核を持ち，卵形整の感覚紏胞上りよくそるつている． 文持細胞は 1 2 層みられ，基宣膜の下には血管が来て

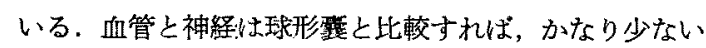
（写真 32）、銀染色に上れば，神絽が基底膜通過後，支 持細胞の核より上方，感覚細胞の下部で複雑な網状をな し，その枝分れは球形需の Macula に扔ける上り多い (写真 33). Macula 以外の部分では内被細胞は扁平で, 固有膜に密着し，固有膜も薄くなつて骨膜と接してい

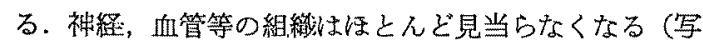
真 34)，骨壁には外側部で前後に走る帯状の軟骨部があ つて，前述の手術等に有利な部分である.

横交通管 Ductus communicans transversus 左右の球形閛を上方で連絡している管で（写真 26）， 中央部では後方の Sinus impar 内へ膨出して, 内ッン パと Sinus impar 内液とを境する膜となつている.

Sinus impar

横交通管の中央部から後方に出る一本の液腔で，内皮 膜に囲まれた盲露である。腔内には標本で Nubecula

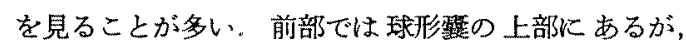
次第に下降して三角柱状となり両側の Lagena の間を 通る (写真 31 ). 後部では左右に分れて Atrium sinus imparisとなり，Weber 氏小骨の Scapium と詨して いる，その間すへて扁平な内皮細胞からなり，特殊なる のを認めない.

側線器官, 皮噟感覚器官, 味蕾

フナの側線器官は体側に見られるものの他に頭部によ

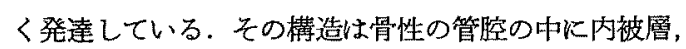
神経，血管が通り，所々に（各体節毎にとされている） Macula を持つている. Macula は背の高い感覚細胞之 支持細胞, その上の Cupula からなり, 感覚毛が $\mathrm{Cu}$ pula に入つている. 外界との交通部として小孔があり， 均質の物質による栓が見られる（写真 35,36$)$.

口腔内，特に㸶頭には非常に多くの味蕾が見られる。 大きな環状の核亮持つ基底細胞と焰状の感覚細胞からら つている，皮腐感覚器官も味蕾の構造淿よく似ている (写真 37).

\section{4. 考察}

魚類の迷路の形熊学的, 組織学的研究は少なく, 比較 的上く研究されているコイ科, ナマズ科打いてる機能 を説明し得る形態は見出されていない。

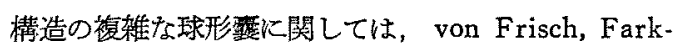
as, de Burlet, Werner, 長谷川, 大久保等の研究があ り，特に重要と思われる耳石 Sagitta と膜迷路との関
俰について, von Frisch? は Sagitta 翼部の内リンパ 中への遊離を示し，またFarkasきは壁からの線維によ る連絡で. Sagitta を弱音器としている. de Burlet ${ }^{11)}$ は翼部が下壁に付き，外側棱と耳石体部が接着すること を示している. 長谷川 ${ }^{12)}$ と大久保 ${ }^{8)}$ は頭部へら状突起 の橋への接着を述べ，Werner ${ }^{13)}$ は1960年これらに関 して固定, 脱灰，包埋操作に上る人工産物が問題で，な 打決定し得ないと述べている，硬い骨腔内死後変化の 早い感覚上皮があり，脱灰過程が耳石におよぼす影響が 大きく，人工産物ができ易いことがこの方面の研究を困 難にしている. Sagitta 翼部の橋部への接着は非常に破 壊され易く，著者の梌索でる初めの二年間はすべて失敗 で, von Frisch や de Burlet の示した写真のことく 接着がはずれていた。そこで大阪市立大学の鈴木清名誉 教授の指導を受け，固定，脱灰，包埋を種々研究した結 果, 生体時の状態を推測し得る良い標本を得ることがで きた、卵形讙，Lagena の耳石は Matrix が粗である ため脱死，脱水による变形はな扣著しいが，Sagittaは 密度が高く、变形が少ないことは辛いでありた。

音波が上く聴器で感受されるためには，particle displacement (縱波) を volume displacement (横波) 飞 変換する場所を有すること(唃乳類では鼓膜)，その横 波が感覚細胞に伝えられる機構をむつこと(耳小骨連 鎖, 外リンパ, 内リンパ, 基礎膜)，矢の際音匠が脱出 する経路を有すること(蝸牛空)，さらに增偪 (インピ 一ダンス整合)の機構をるつこと（耳小骨のてこ比，鼓 瞙之前庭空の面積比による) が必要とされている.フナ の場合これを検討すると，水中の音波は体壁を通つて， ガスを充たす醥に和いて横波となる，この際魚体の輻は $1000 \mathrm{cps}$ の音波の約 70 分の 1 波長であるから，解の各 部での位相差は無視してよいと思われる。橆の前房から 三つの Weber 氏小骨, Sinus impar 内液, 横交通管 の内リンバ液を通じて，球形型へ伝播する経路を持つて いる. 球形整の橋部は薄い膜状で，振動して Sagitta 翼 部に伝え，剛体である耳石は上下縁に固着しているた め, Macula 上の感覚毛の入つている膠様物質を振動さ せると孝えられる．Sagitta が軽量であることは，小さ な音玨で振動するに有利である，橋部の下の外リンパ腔 恃広、頭蓋内の cavum subdurale へ音圧脱出の経路を

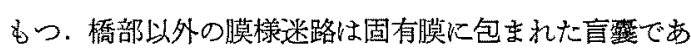
るため，音压の逃げることは極めて少ない，特㴹路上 部へは逜垔管に狭䇡部あるため (写真 15) 音圧は拔け 難い，さらに鳔に比して橋部は非常に小さく，增幅が大 
きいと思われる。球形整の Macula では豊富な血管と 神経が見られる。

このように音刺激感受部位としてすべて条件を備古る のは球形敕であり，形態上他の部分での感受は考学られ ない.

\section{IV. 結 語}

コイ科フナ Carassius auratus Linné に执いて迷路 の形態を研究し，聴覚実験とともにその聴覚感受部位を 検討した.

1. 各種感覚器官の破罗実験を行 万と, 迷路下部(球

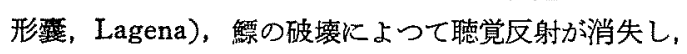

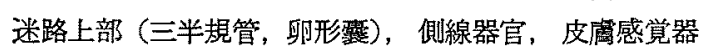
官の破壊では聴覚反射が残つている。

2. 球形慗恃鳔より Weber 器官, Sinus impar 介して音圧の伝わる経路をるち，しかも外界より音圧を 受ける鰂と比較して，橋部は面積がはるかに小さい，

3. 耳石 Sagitta は Macula の上下緑に上下棱で固 着し，橋部には翼部が接着して，感覚毛の入る膠椂物質 は耳石内面に包まれている。

4. 球形整の橋部で内リンパは外リンパと境され，こ の外リンパ腔は頭蓋内の Cavum subdurale に連なり 音压脱出路をなするのと考劣る。球形裂と連なる Lage-

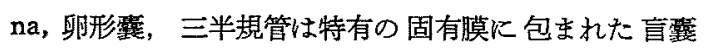
で，音圧の脱出は非常に少ないと考えられる．

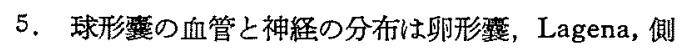
線器官と比較して非常に豊富である。

以上述べたように, 球形蓶が音を適応刺激とする感賞 器,すなわら恥器であると考えられる.

\section{主要文献}

1) 山本常市：魚の耳の形態と乞の機能, 㓣文社, 1954. 2) 工藤得安, 他: 耳石, 解剖学発生学业書 1 1951. 3) Bierbaum, G.: Untersuchungen über den Bau der Gehörorgane von Tiefseefischen. Zeitschr. Wiss. Zool., 111; 281, 1914. 4) Parker, G.H. and Van Heusen: The receptson of mechanical stimuli by the skin, lateral-lineorgans and ears in fishes, especially in amiurus. Amer. J. Physiol, 44; 463, 1917.

5) Manning, F.B.: Hearing in the goldfish in relation to the structure of its ear. J. exp. zool, 41 ; 5, 1924 . 6) von Frisch, $K$. and S. Dijkgraaf: Hearing in Rhoxinus. Biol. Rev, 11; 210, 1936. 7) von Frisch: The Physiology of Fishes. New York Academic Press Inc., 1957. 8) 大久保博舜：魚の迷路機能について, 日耳 年, $51 ； 22,1947$ (昭22). 9) Katsuki, Y., S. Yos. hino and J. Chen: Action currents of the single lateral-line nerve fiber of fish. Jap. J. Physiol, 1; 87, 179, $1950 . \quad$ 10) Katsuki, Y., S. Yoshino and J. Chen: Neural mechanism of the lateral-line organ of fish. Jap. J. Physiol, 1; 264, 1950. 11) De Burlet, H.M: Anatomisches zur Hörfähigkeit der Siluroiden. Zeitschr. Anat. Ent-gesch., 89; 11, 1929. 12) 長谷川高钽：魚の感音装置，日耳年，55; 634, 1952 (昭27). 13) Werner, Cl. F.: Das Ge" hörorgan der Wirbeltiere und des Menschen. Leipzig, 1960. 14) Ladd, C. et al: Comparative animal Physiology. London, 1961. 15) 本城市次 郎：動物の感覚, 岩波書店, 1961. 16) 末広恭雄： 魚類学，岩波書店，1960。17) 関正次：組織検査法， 杏林書院, 1961.

稿を終るにあたり，䅂始御舁切なる御指遵を 睗つた恩師長谷川高敏教授に深甚なる感謝の意 を表します。また組織学的研妴に打いて衔指 導, 御助言を賜つた大阪市立大学解剖学数室; 鈴木清名誉教授に惑心上り感謝します。

本論文の要旨は，第 123 回，第 125 回，第 128 回，第 129 回日本耳鼻咽喉科学会大服地方 会に怙いて発表した。

（原稿到着二昭和 41.2 .21 日） 


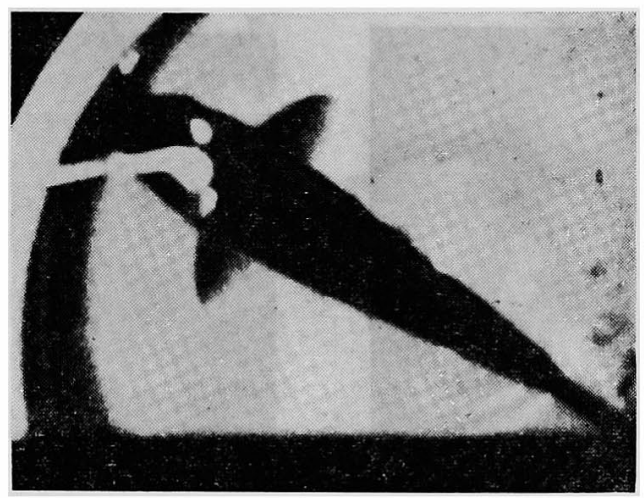

写真 1 鮒の聴覚反射

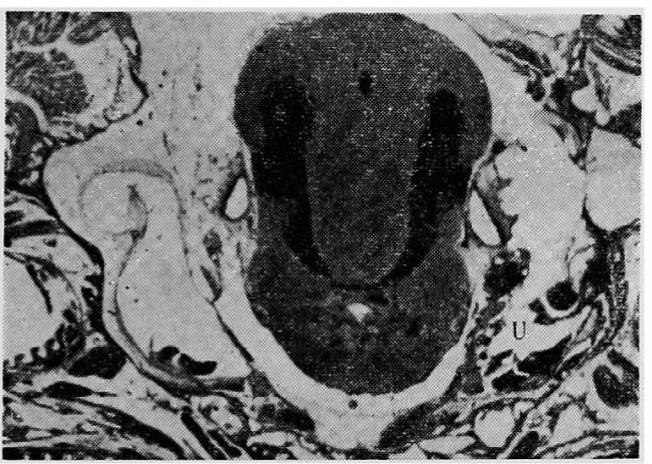

写真 2 右側迷路上部破壞 U. $\times 12$

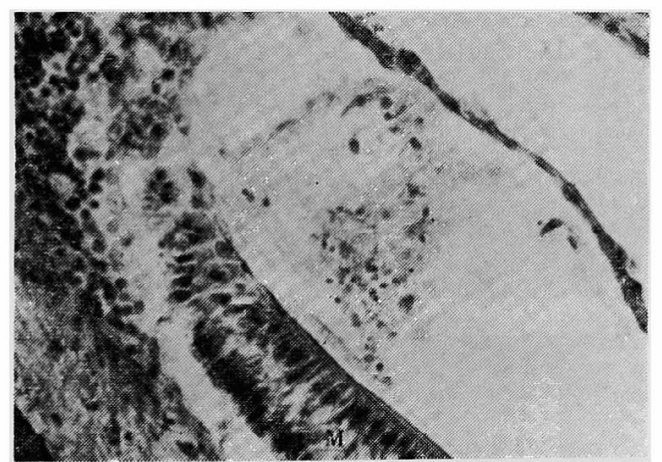

写真 4 頭部側線器官の破壊 M. Macula $\times 400$

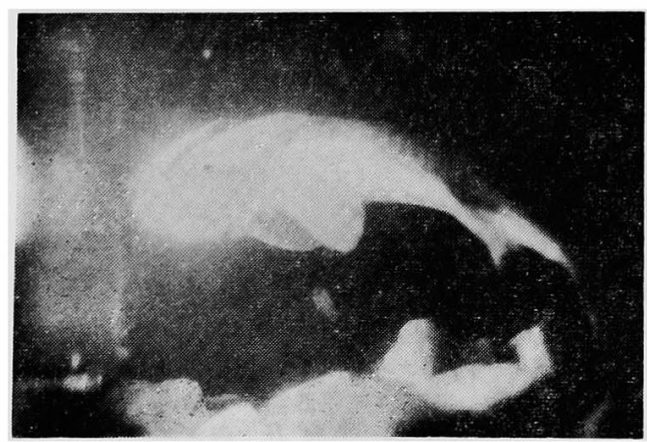

写真 6 右迷路上部破壊後

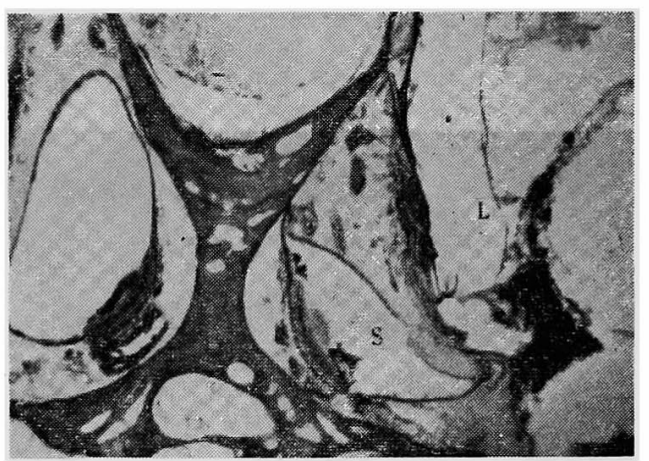

写真 3 右側迷路下部破壊 S 球形㖇 L. Lagena $\times 30$

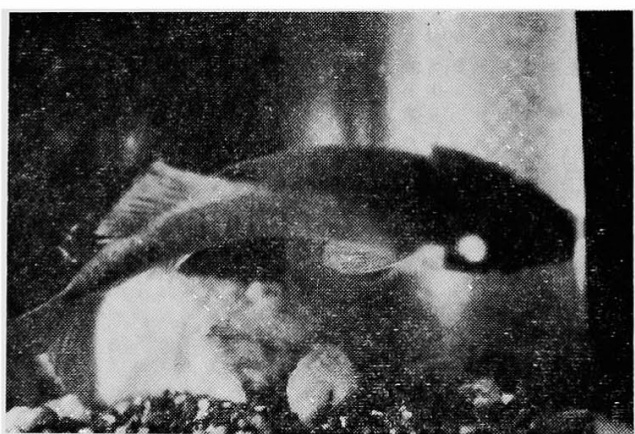

写真5 右迷路上部破壤後

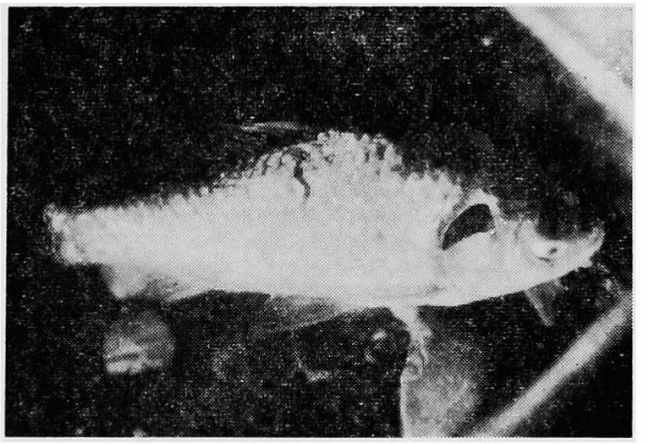

写直 7 右迷路下部破壤後 


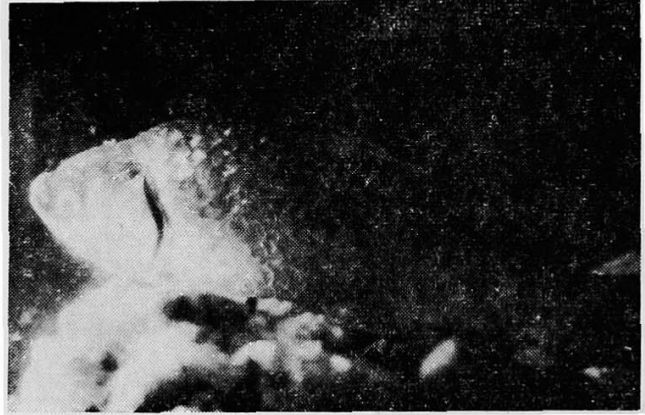

写真 8 僄 穿 刺 後

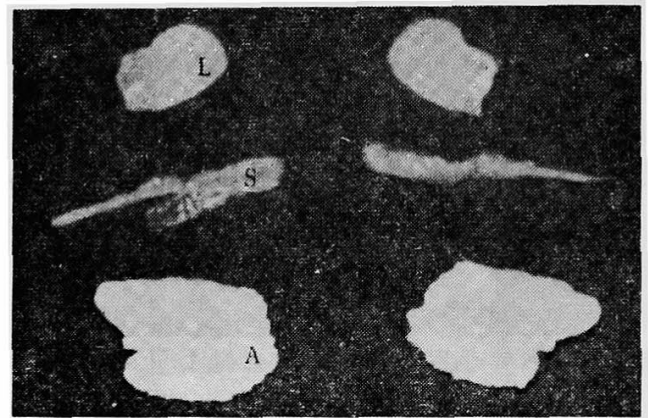

写真 10 L. Lapillus, S. Sagitta, A. Asteriscus 左は内面, 右は外面

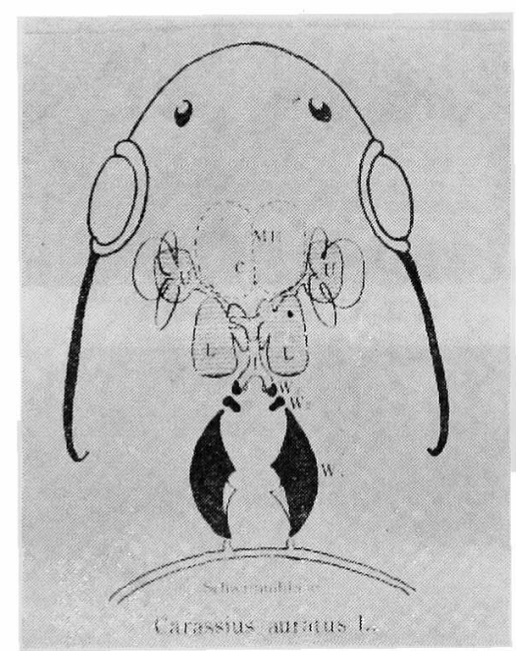

写真 12 U 卵形莜, S 球形雚, L. Lagena, C 横 交通管，I 不同洞，W $1,2,3$ Weber 氏小骨

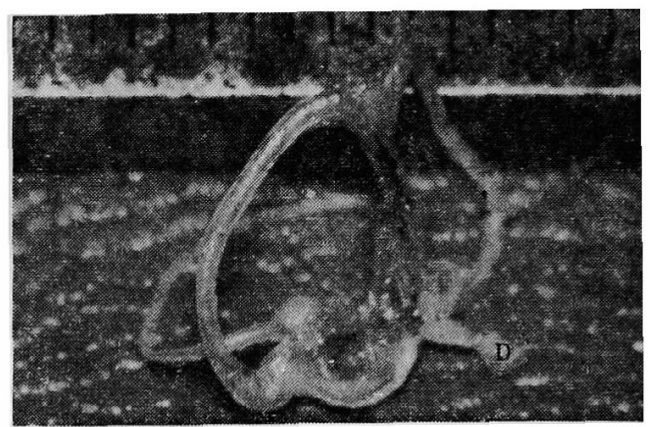

写真 9 右側迷路上部，固有膜に包むれている D. 連嫼管, 上方の目盛 $1 \mathrm{~mm}$

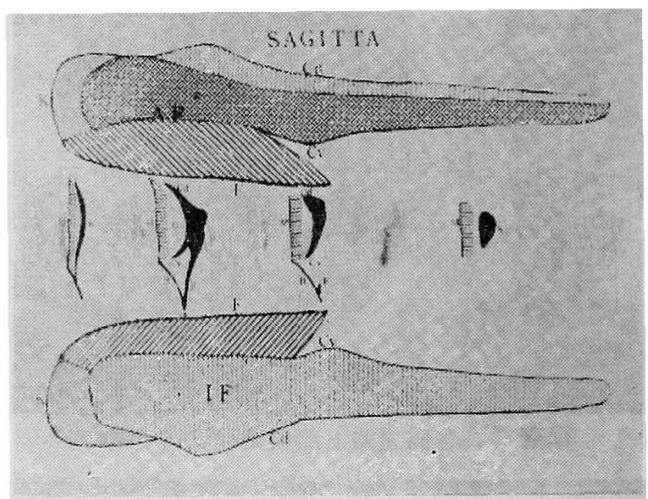

写真 11 Sagitta 模式図，中央は断面，上は外側 面, 下は内側面

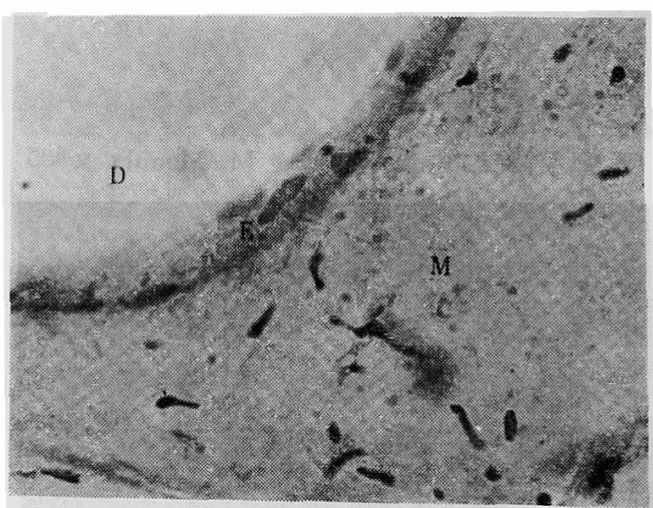

写真 $13 \mathrm{M}$ 固有膜, $\mathrm{E}$ 内被膜, $\mathrm{D}$ 半規管 内リンパ腔 $\times 400$ 


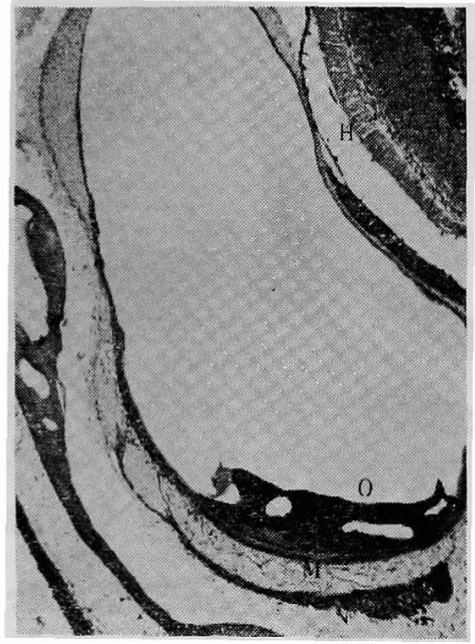

写真 14 卵形韮，O 耳石, M. Macula, N. 神 経, H. 中脳 $\times 40$

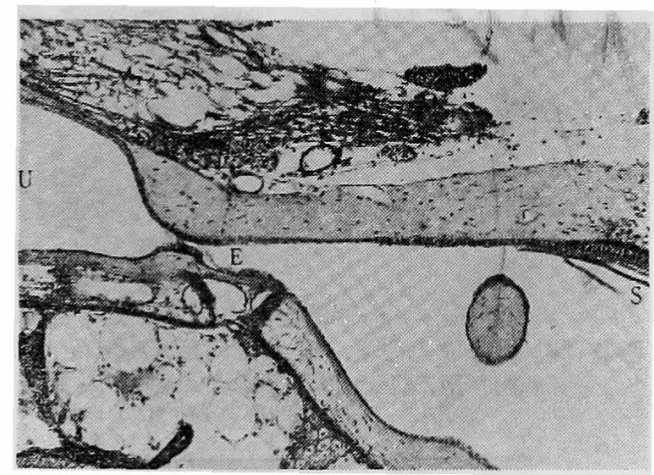

写真 16 連囊管，S. Sagitta の頭部，E. 犷突部， V. 卵形囊 $\times 60$

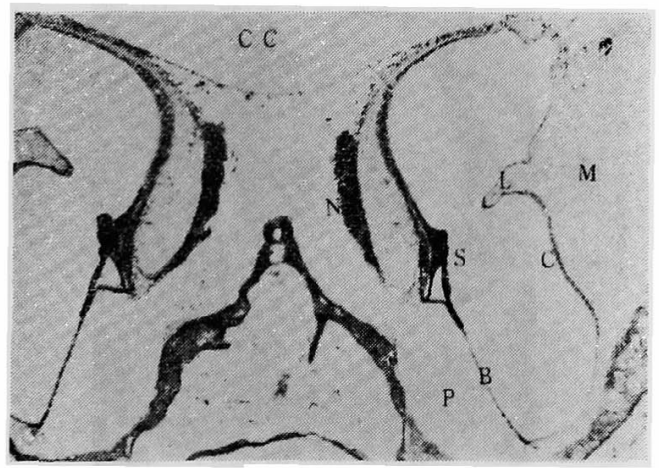

写真 18 外リンパ腔頭蓋腔交通部, CC. 頭蓋腔, M. 固有膜，B. 橋部，C. 特殊細胞，S. Sagitta， L. 外側稜, N. 神経, P. 外リンパ腔 $\times 40$

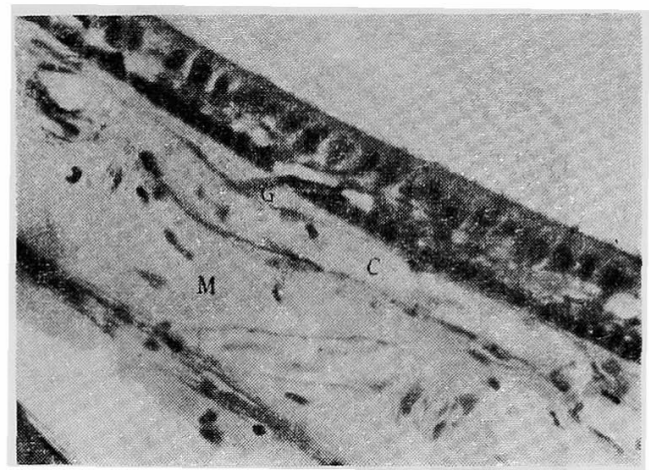

写真 15 卵形露 Macula, M. 固有膜, G. giant reve fiber C. 血管 $\times 600$

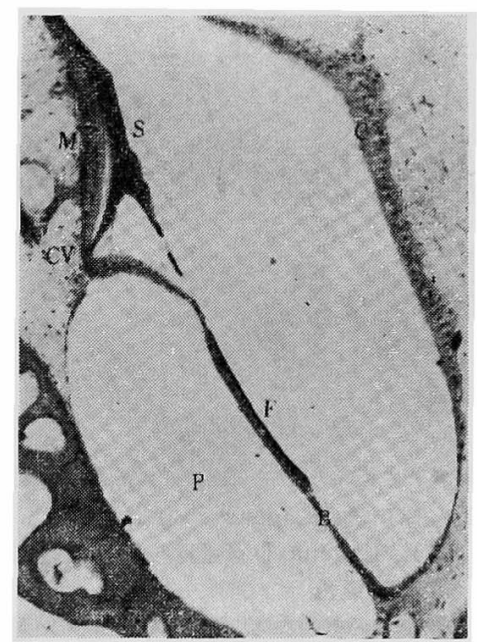

写真 17 球形露，P. 外りンパ腔，B. 橋部，S. Sagitta，F. 翼部，M. Macula, C. 特 殊細胞, CV. 下稜固着部 $\times 120$

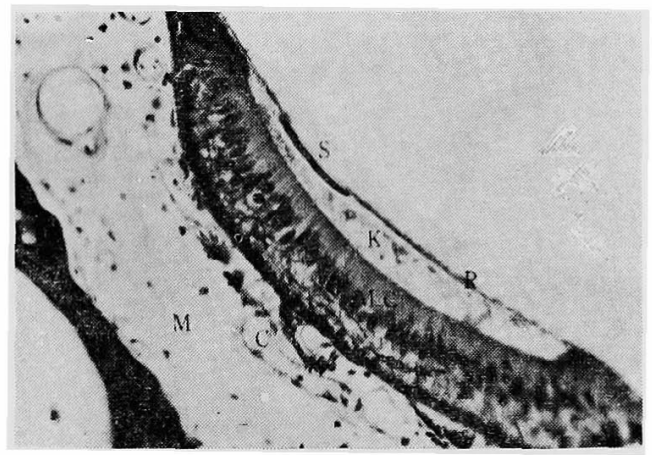

写真 19 球形蹓後部, S. Sagitta, ${ }^{5}$ K. 膠椂物質, C. 血管，R. Randfaser，M. 固有膜， $\times 400$ 銀染色, MC. Macula 


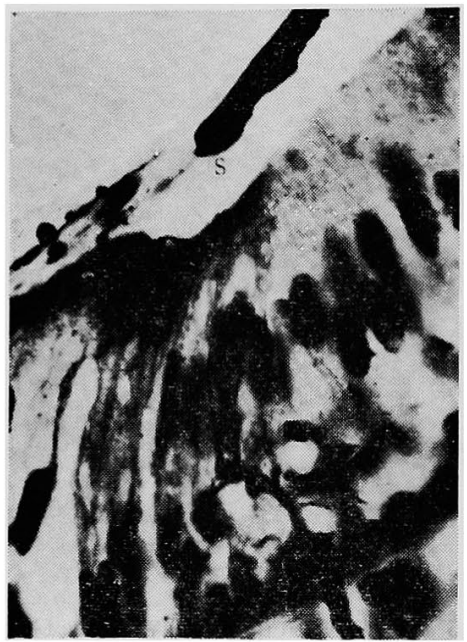

写真 20 Macula 下稜固着部, S. Sagitta $\times 2000$ 銀染色

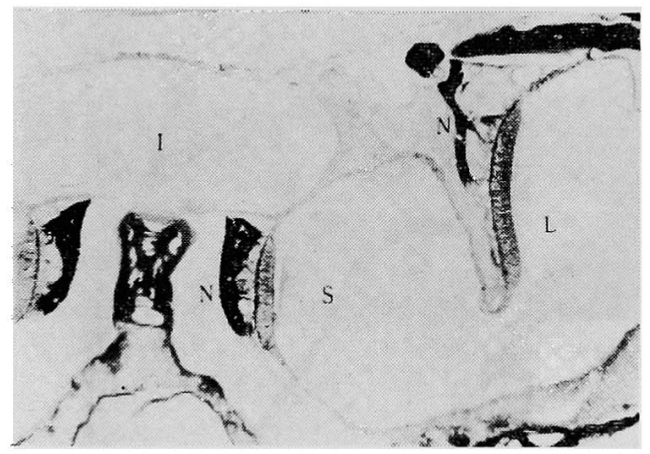

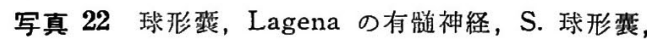
L. Lagena I. 不同洞，N. 有䯣神経 $\times 30$ 骮蜼染色

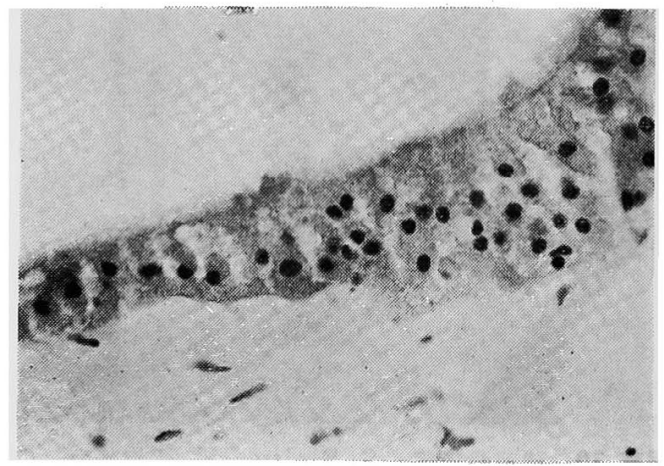

写真 24 外侧稜下部の特殊細胞 $\times 600$

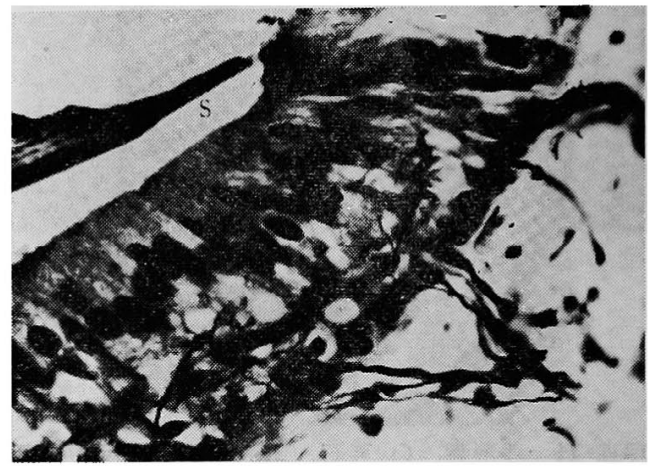

写真 21 Macula 上稜固着部の神経, S. Sagitta $\times 1500$ 銀染色

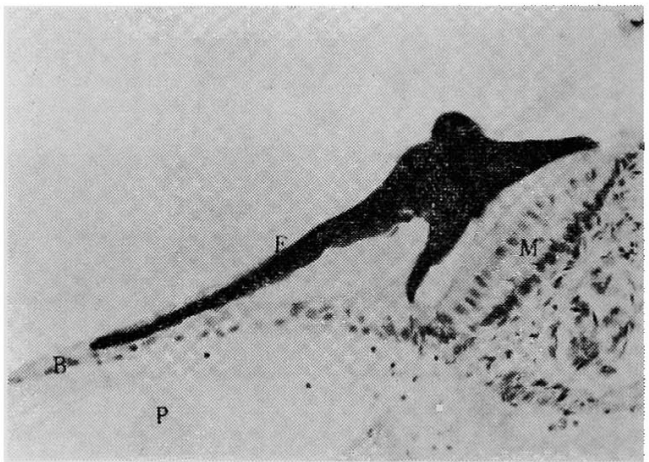

写真 23 球形醛中央部， B, 橋部，F. Sagitta の翼 部. M. Macula P.聂外リンパ腔 $\times 300$

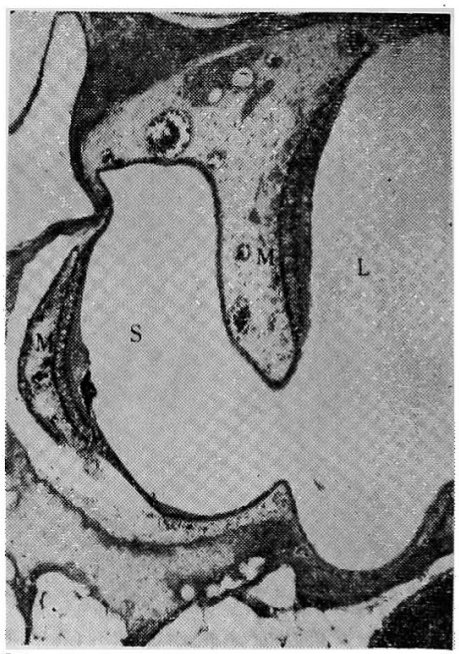

写真 25 球形襄, Lagena 交通部, S. 球形峦 L. Lagena, M. Macla $\times 60$ 


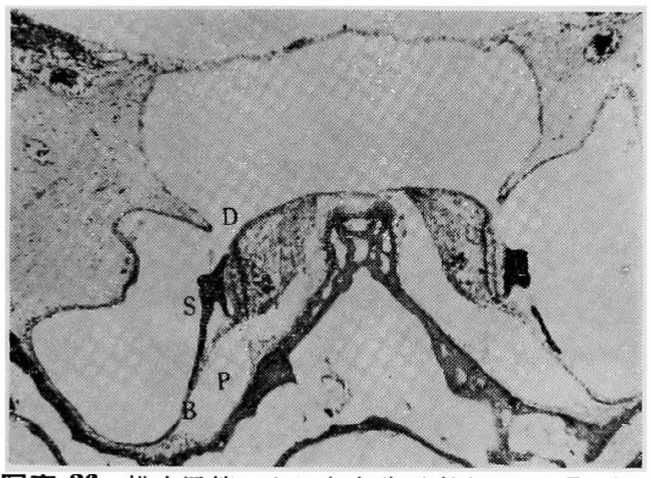

写真 26 横交通管による左右球形覇交通部，D. 横交 通管 S. Sagitta，B. 橋部， P. 外リンパ腔 $\times 40$

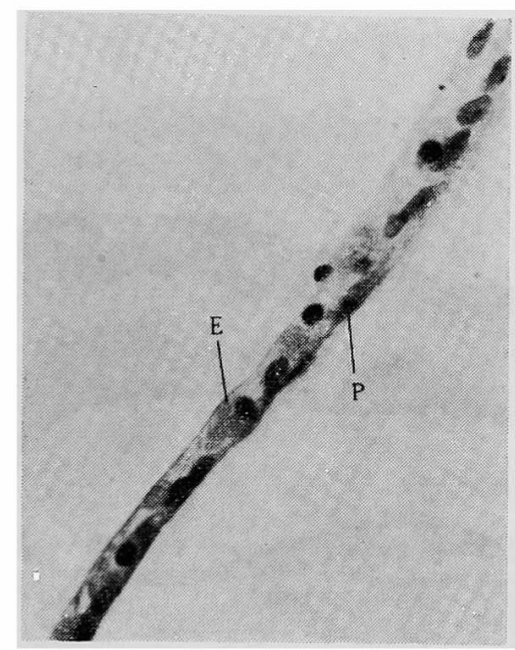

写真 28 橋部の細胞二種, E. 内リンパ腔上皮, P. 外リンパ腔内皮 $\times 1000$

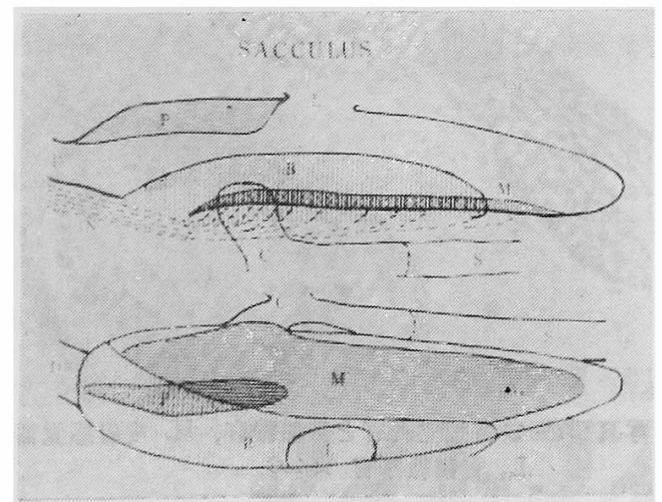

写真 30 球形襄の模式図，耳石を除く，上は上方よ り，下は側方よりみる。

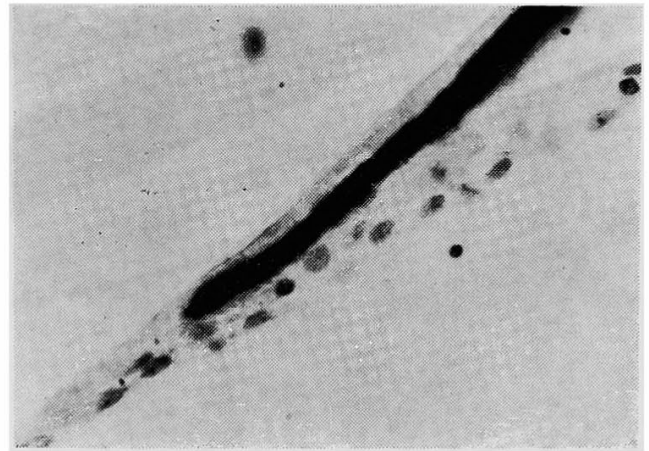

写真 27 Sagitta 翼部の橋への接着 $\times 1000$

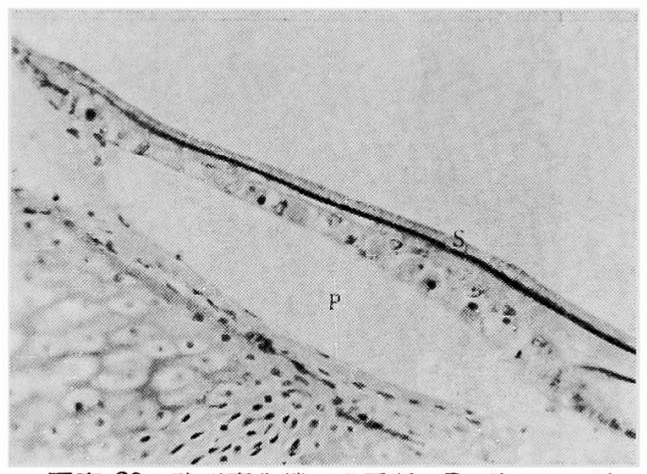

写真 29 球形覇先端の水平断, P. 外リンパ腔 S. Sagitta 頭部

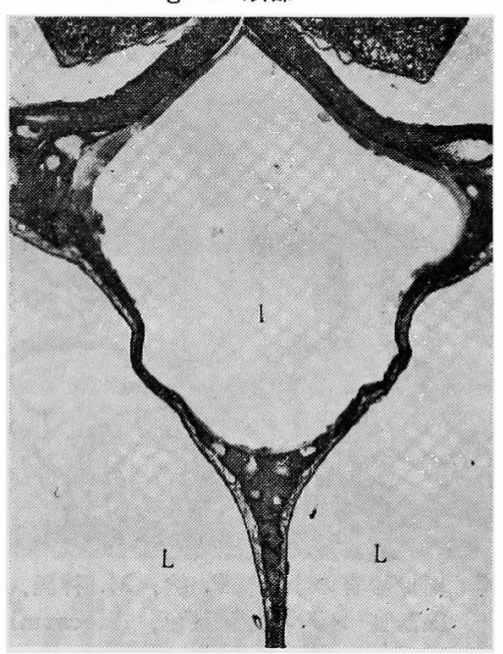

写真 31 Lagena 後部之不同洞, L. Lagena I. 不同洞 $\times 60$ 


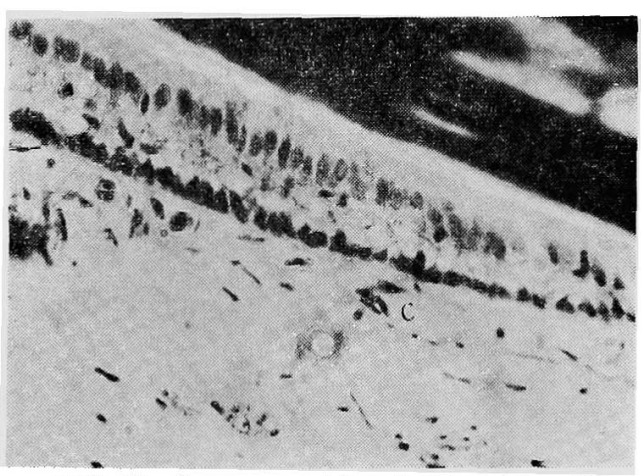

写真 32 Lagena の Macula C. 血管 $\times 600$

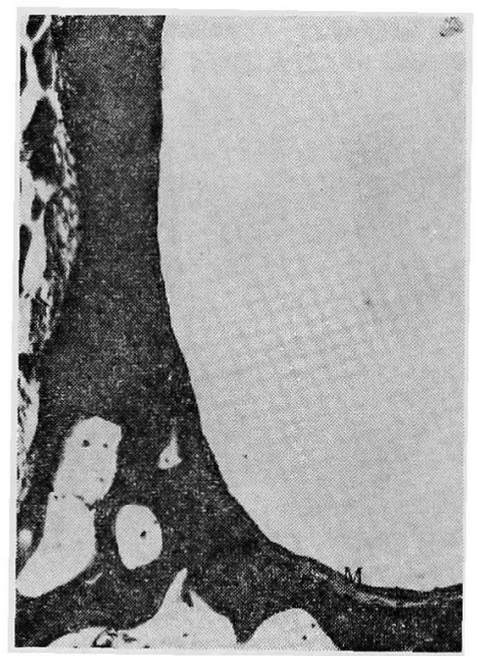

写真 34 Lagena M. 固有膜 $\times 60$

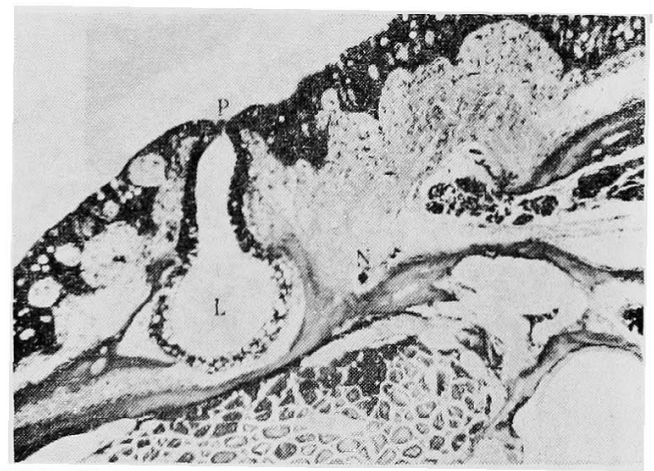

写真 36 側線器官の小孔， P. 栓, M. 神経, L. 侧 楾器官 $\times 200$ 䯣鞘染色, Azocarmin

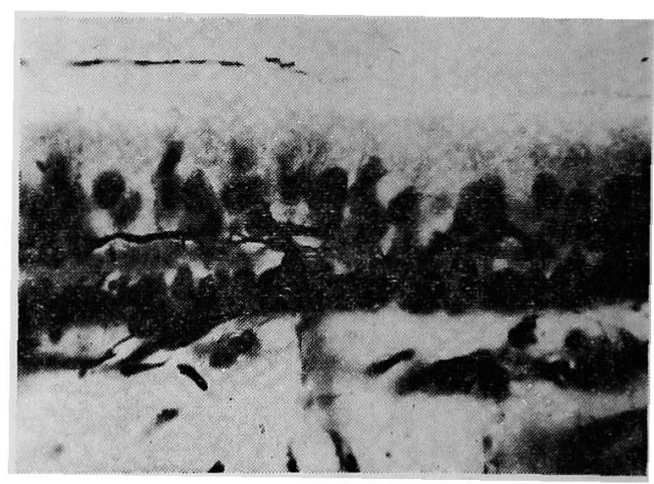

写真 33 Lagena の Macula $\times 800$ 銀染色

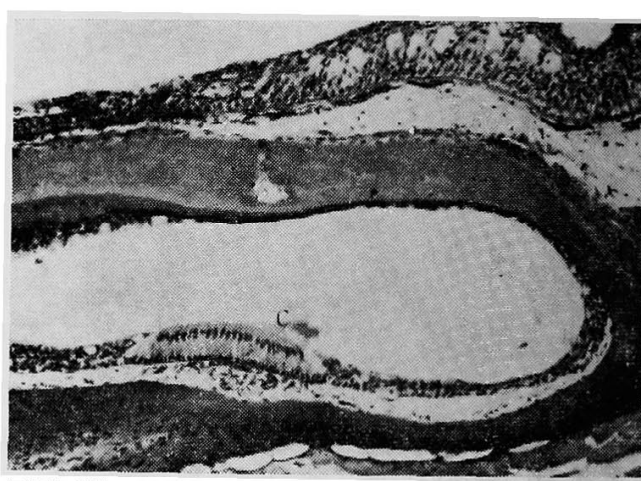

写真 35 側線器官の Macula, C. Cupula, ×200

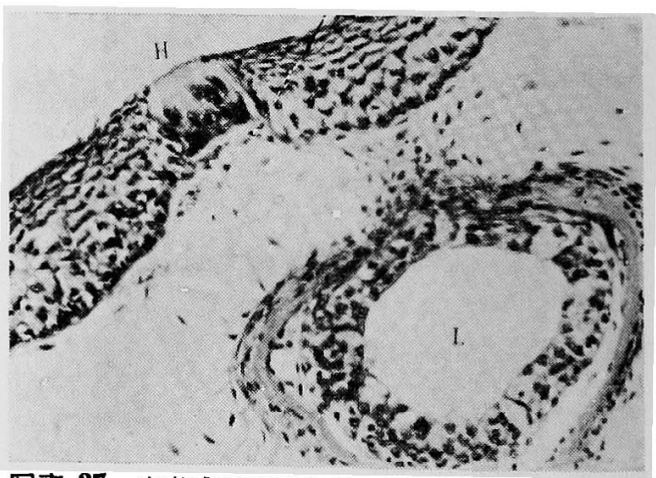

写真 37 皮痈感覚器官と側線器官, H. 皮虚感覚器 L. 官側線器官 $\times 400$ 